\title{
Key competencies of university graduates to achieve sustainable development
}

\author{
Anastasiya Pesha* \\ Ural State University of Economics, 8 Marta, 62, 620144 Ekaterinburg, Russia
}

\begin{abstract}
The number of studies devoted to the development of key competencies for sustainable development in higher education has been growing in recent years. The relevance of the topic of the formation of supraprofessional competencies of future specialists with an emphasis on achieving sustainable development prompted this review study. The purpose of this study is to analyze approaches to terminology and the formation of a number of key competencies of university graduates in the field of sustainable development and to analyze thematic research trends in this area in 2017-2020. The results of this review form the basis for further discussion of approaches, tools and pedagogical technologies for the formation of university students' competencies in the field of sustainable development to meet the current and future needs of countries and society as a whole.
\end{abstract}

\section{Introduction}

One of the most interesting and promising areas of research in the field of non-professional competencies, in our opinion, is the study of the key competencies of sustainable development. The concept of sustainable development and its basic idea of ensuring life on Earth for future generations and meeting the needs of the present generation was developed after the report of the Brundtland Commission to the World Commission on Environment and Development (1987) [1]. Since that time, the concept has been developed in various areas of life. One of the directions for the development of the concept of sustainable development is the formation of a number and the development of competencies of future specialists, university students to achieve sustainable development.

The UNESCO 2030 Agenda is based on 17 Sustainable Development Goals, which describe the main problems of human development [2]. In a period of turbulence and instability of socio-economic and political processes, in the context of global environmental risks and disasters, the world scientific and political community pays attention to the development of competencies in the field of sustainable development. Cutting-edge research in this area was carried out by such scientists as De Haan G. (2006), Rieckmann M (2012), Wiek et al., (2011) [3, 4, 5]. It was on their basis in 2017 in the UNESCO document "Education for sustainable development goals: learning objectives" a list of key sustainable development competencies for education appeared [2, p. 10].

\footnotetext{
* Corresponding author: myrabota2011@gmail.com
} 
Research in the development of students' competencies necessary for sustainable development is carried out in such scientific areas as education and pedagogy, economics and management, computer science, psychology, health care and others.

Existing publications include a review of the literature on sustainable development. The authors emphasize their concept and formulation of higher education programs, as well as the relevance of the concepts for stakeholders in higher education around the world [6]. Among the works of greatest scientific interest in the field of competence development, there is also empirical research based on the students' ideas, experts view and opinions of other stakeholders in higher education about the essence of competencies $[4,5,7]$. The most cited publication in the database is a review article prepared by scientists from Arizona State University, USA, Wiek A., Withycombe L. \& Redman C.L. in 2011 [5]. Discussion article on the key competencies of sustainable development, their essence and classification. In 2017, when developing key competencies for education at UNESCO, the authors of the project rely on research carried out by A. Wieck and his team [2, p. 10].

In our work, we tried to conduct a systematic review of publications based on the data of abstract research by Web of Science and RSCI in the field of determining the key competencies of university graduates to achieve sustainable development.

\section{Materials and Methods}

In this work, we carried out a bibliographic analysis of the Web of Science and RSCI databases on the topic of competencies in the field of sustainable development, with an emphasis on publications of the last four years (from 2017 to 2020) and research on this concept in higher education. The search was carried out by titles and keywords of publications. In Table 1, we present a description of the research sample with the logic of choosing the key publications presented in the work.

Table 1. Study sample description.

\begin{tabular}{|c|c|c|c|}
\hline \multirow[t]{2}{*}{ Criterion } & \multirow[t]{2}{*}{ Description } & \multicolumn{2}{|c|}{$\begin{array}{c}\text { Publications in the database } \\
\text { (pcs.) }\end{array}$} \\
\hline & & $\begin{array}{l}\text { Web of } \\
\text { Science }\end{array}$ & $\begin{array}{l}\text { RSCI }(E- \\
\text { Library) }\end{array}$ \\
\hline $\begin{array}{l}\text { Search definition (in the } \\
\text { title of the article) }\end{array}$ & competenc $* * *$ & 62212 & 102801 \\
\hline Publication period & $2017-2020$ & 18053 & 39165 \\
\hline Research Areas $\left(\mathrm{n}_{1}\right)$ & $\begin{array}{l}\text { Education; Economy; Management; } \\
\text { Business; } \\
\text { Communications; Behavioral sciences; } \\
\text { Social Sciences, Engineering. }\end{array}$ & 12807 & 32526 \\
\hline $\begin{array}{l}\text { Clarification in the } \\
\text { research topic }\left(\mathrm{n}_{2}\right)\end{array}$ & «Higher education» & 1118 & 1070 \\
\hline Number of citations $\left(n_{3}\right)$ & $\begin{array}{l}5 \leq \text { citations } \leq 57 \mathrm{WoS} \\
5 \leq \text { citations } \leq 54 \mathrm{RSCI}\end{array}$ & 115 & 120 \\
\hline $\begin{array}{l}\text { Clarification in the } \\
\text { research topic }\left(\mathrm{n}_{4}\right)\end{array}$ & «sustainable development» & 29 & 1 \\
\hline
\end{tabular}

The paper also provides an overview of approaches to the interpretation and set of key sustainable development competencies identified by researchers. The main challenge here was to define a set of core competencies for sustainable development. 


\section{Results and discussion}

In total, 41 scientific publications have been posted on the topic of sustainable development competencies in the RSCI, of which over the last 4 years (2017-2020) 20 publications, and with a citation of $\leq 5$ only 1 . In the WoS database on the topic of competencies for sustainable development, 104 publications were posted for the period under study. The sample $n 4$ includes 29 works, 9 of which are in the top 20 publications in terms of the number of citations, which means they are of the greatest interest in the international scientific community [eg $8,9,10]$.

We carried out a semantic analysis and analysis of publications by their types of publications, selecting the 115 most cited works $(5 \leq$ citations $\leq 57)$ according to the definition "Competenc $* * * "$ with clarification in the topic of the work "Higher education" in the WoS database (n3) and 120 publications $(5 \leq$ citation $\leq 54)$ for the same search query in the RSCI database (n3). Figure 1 shows the semantic analysis of the keywords of publications. The word cloud shows that the most frequently used keywords in works, in addition to words from the search query: students, assessment, motivation, learning, skills, pedagogy, model, innovation, digital competence, sustainable development competence.

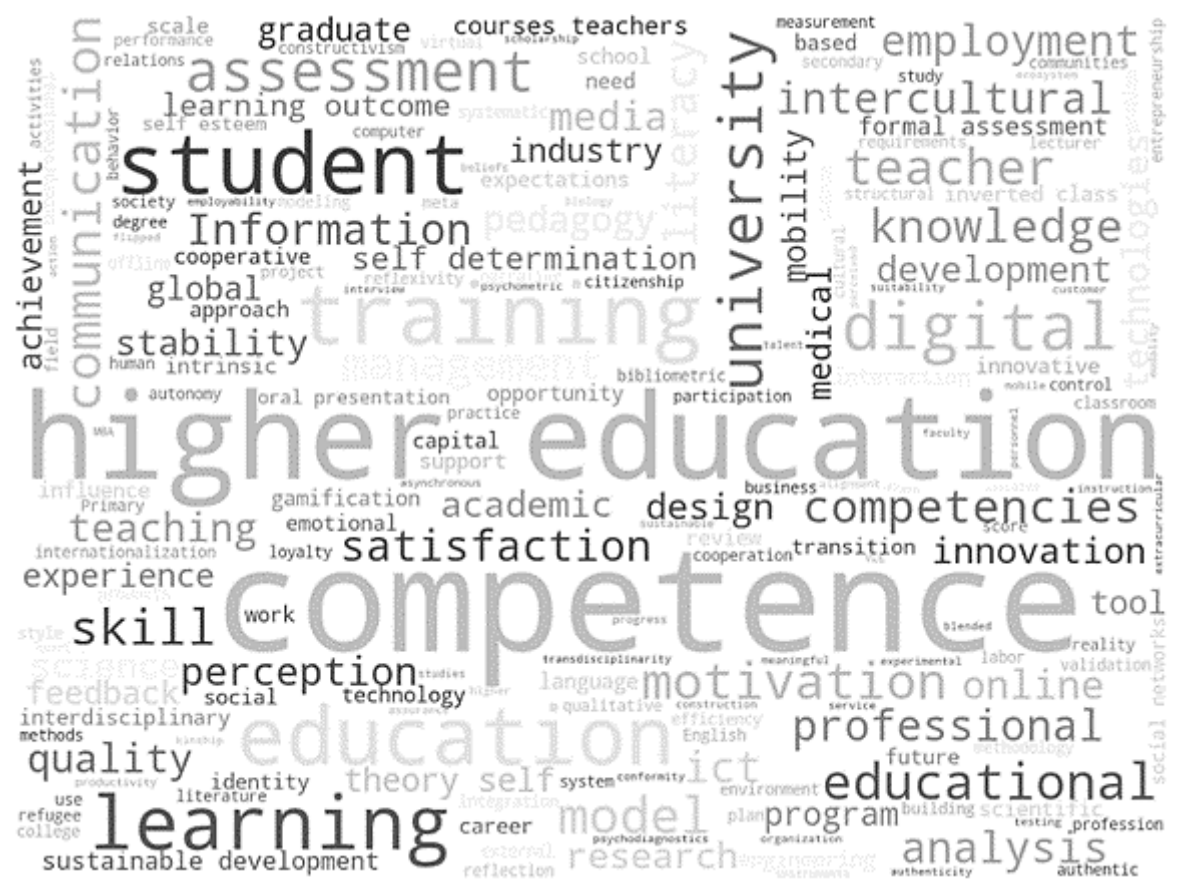

Fig. 1. Semantic keyword cloud of TOP-105 publications in the WoS database in the period from 2017 to 2020 .

In table 2, we present the distribution of the top 30 cited publications $(n=29, n=1)$ on the research topic, indexed in the WoS and RSCI databases, respectively, on the research topic by type of work (review, theoretical, empirical) with a citation of $\geq 5$. In the table, we also calculated the average number of citations per publication for each type of work (Mn) in the total volume of selected 30 publications (n4). Despite the high citation index of publications representing the results of empirical research, the most valuable for researchers are review publications that present the results of a systemic bibliographic analysis of various aspects of the concept of competencies for sustainable development with clarification on a variety of topics and research definitions. 
Table 2. Distribution of the most cited works 2017-2020 sample population $n 4$ by type and number of citations.

\begin{tabular}{|c|c|c|l|}
\hline Type & $\begin{array}{c}\text { Total } \\
\text { works } \\
\text { from n4 }\end{array}$ & Mn4 & \multicolumn{1}{|c|}{ Most cited publications (n4) } \\
\hline Review papers & 6 & 30,2 & $\begin{array}{l}\text { Cebrián et al., 2020; Jelonek \& Urbaniec, 2019; } \\
\text { Lambrechts et al., 2017; Lozano et al., 2017; Mindt \& } \\
\text { Rieckmann, 2017; Sterling et al., 2017 [11-16]. }\end{array}$ \\
\hline Theoretical & 9 & 11 & $\begin{array}{l}\text { Dlouhá et al., 2019; Krechetov, 2017; Mulder, 2017; } \\
\text { Sahakian \& Seyfang, 2018; Shukshina, Suldina, 2019; } \\
\text { Shephard et al., 2019; Tejedor, 2019; Valor et al., 2020; } \\
\text { Zuzeviciute et al., 2017 [17 - 25]. }\end{array}$ \\
\hline Empirical & 16 & 15,8 & $\begin{array}{l}\text { Albareda-Tiana et al., 2018; Alvarez-García et al., 2018; } \\
\text { Brassler \& Dettmers, 2017; Brundiers et al., 2021; } \\
\text { Demssie et al., 2019; Eizaguirre et al., 2019; Faham et al., } \\
\text { 2017; Lambrechts et al, 2018; Lambrechts et al., 2019; } \\
\text { Lozano et al., 2019; Molderez \& Fonseca, 2018; Quelhas } \\
\text { et al., 2019; Sánchez Carracedo et al., 2018; Schulze et al., } \\
\text { 2019; Waltner et al., 2019 [8, 9, 10, 26 - 37]. }\end{array}$ \\
\hline
\end{tabular}

The interest and relevance of the topic of developing competencies for sustainable development in higher education is high among scientists for the last three years $[8,10,19]$. The most cited work (57 citations in WoS, 125 in the Google Scholar database) for the search query we generated is a review article by Lozano Ryu and others, revealing the structure and relationship of 12 existing pedagogical approaches implemented in education with key competencies for sustainable development, which the authors highlight 20 [14]. A number of publications from the pool of works analyzed by us are also focused on the analysis of effective didactic approaches and methods of pedagogical work for the development of competencies for sustainable development. Molderez, I., \& Fonseca, E. (2018), Lozano, R. et al. (2019), Tejedor, G., Segalas, J. et al. (2019) [23, 32,3 3]. Molderez, I., \& Fonseca, E. (2018) point out the need to reorient education towards a combination of interdisciplinarity, creativity and fun to ensure that students acquire competencies for sustainable development [33]. The results of the empirical research carried out by the authors have shown the greatest efficiency in the formation of competencies of a combination of pedagogical techniques and actions.

In Table 3, we present the key sustainable development competencies identified by various authors. The list of competencies is presented in the context of the most frequently encountered and accepted by the majority of scientists to the singularly encountered interpretations. It can be noted that the key competencies in the field of sustainable development: critical and systems thinking, predictive or strategic competence, normative competence and competence in the field of cooperation and interpersonal relations.

Table 3. Approaches to determining the list of key competencies in the field of sustainable development.

\begin{tabular}{|c|l|}
\hline Competencies & \multicolumn{1}{|c|}{ Authors } \\
\hline Critical thinking & $\begin{array}{l}\text { Lambrechts, et al., 2013; Rieckmann, 2012; Taimur, Sattar, 2019; UNESCO, } \\
\text { 2017; Wiek et al., 2011[2, 4, 5,38, 39] }\end{array}$ \\
\hline Systems thinking & $\begin{array}{l}\text { Lambrechts, et al., 2013; Rieckmann, 2012; UNESCO, 2017; Taimur, Sattar, } \\
\text { 2019 [2, 4, 38, 39] }\end{array}$ \\
\hline $\begin{array}{c}\text { Predictive competence / } \\
\text { strategic competence }\end{array}$ & $\begin{array}{l}\text { Rieckmann, 2012; Taimur, Sattar, 2019; UNESCO, 2017; Wiek et al., 2011; De } \\
\text { Haan, 2006 [2, 3, 4, 5, 39] }\end{array}$ \\
\hline Normative competence & Taimur, Sattar, 2019; UNESCO, 2017; Wiek et al., 2011 [2, 5, 39] \\
\hline Cooperation & De Haan, 2006, C. 24; Lambrechts, et al., 2013; Rieckmann, 2012; Taimur, Sattar, \\
& 2019; UNESCO, 2017; Wiek et al., 2011 [2, 3, 4, 5, 38, 39] \\
\hline Interpersonal competence & Lambrechts, et al., 2013; Taimur, Sattar, 2019; UNESCO, 2017 [2, 38, 39]
\end{tabular}


Table 3. Continued

\begin{tabular}{|c|l|}
\hline $\begin{array}{c}\text { Self-awareness / self- } \\
\text { knowledge }\end{array}$ & De Haan, 2006, C. 24; Rieckmann, 2012 [3, 4] \\
\hline Complex problem solving & De Haan, 2006; Lambrechts, et al., 2013; Rieckmann, 2012 [3, 4, 38] \\
\hline Planning and innovation & De Haan, 2006; Lambrechts, et al., 2013 [3, 38] \\
\hline $\begin{array}{c}\text { Interdisciplinary } \\
\text { competence }\end{array}$ & Lambrechts, et al., 2013; Rieckmann, 2012 [4, 38] \\
\hline
\end{tabular}

\section{Conclusions}

We analyzed the main existing approaches to the definition and structure of sustainable development competencies. Currently, there is a huge amount of research, projects and frameworks that are implemented at different levels from the level of individual companies to global international projects in the field of the concept of competencies. In our study, it is too early to put an end to the interpretation of the concept of sustainable development competencies and their structure, since every day gives new food for thought and analysis. There is a need to unify approaches to their classification and to make adjustments to state educational standards.

The existing diversity of approaches to the interpretation of competencies in the field of sustainable development, in our opinion, creates opportunities for disclosing the ideas of a competence-based approach from various sides and thereby allows developing the concept of competencies and discovering new and valuable for the future sustainable development of the individual, the labor market, the education system, economy and social development in general.

We consider it advisable to develop a wider range of non-professional competencies during higher education, including in the field of sustainable development, which provide the university graduate with effective adaptation in the labor market, readiness for environmental challenges, as well as a high level of productivity in solving various kinds of problems.

Research on the factors and conditions for the formation of key competencies in the field of sustainable development is relevant. It is not enough to explore the possibilities of forming competencies, it is necessary to adequately assess a wide range of factors influencing this process: from intrapersonal and interpersonal to factors of world, global impact.

It is necessary to continue and develop research topics related to meeting the needs of the labor market in the level of development of students' competencies. In this direction, there is also a wide field for the continuation of scientific research, especially in matters of the readiness of employers to become full stakeholders in the educational process and to take part in the active involvement of future specialists in the economies of countries.

\section{Acknowledgements}

The study was carried out with the financial support of the Russian Foundation for Basic Research in the framework of scientific project No. 19-29-07435

\section{References}

1. World Commission on Environment and Development Our Common Future (1987)

2. UNESCO. Education for sustainable development goals: learning objectives (2017)

3. G. De Haan, Environmental Education Research, 12(1), 19 (2006)

4. M. Rieckmann, Futures, 44(2), 127 (2012)

5. A. Wiek, L. Withycombe, C. L. Redman, Sustainability science, 6, 203 (2011) 
6. T. Lans, V. Blok, R. Wesselink, Journal of Cleaner Production, 62, 37 (2014)

7. A. E. J. Wals Mirroring, International Journal of Sustainability in Higher Education, 11(4), 380 (2010).

8. S. Albareda-Tiana, S. Vidal-Raméntol, M. Pujol-Valls, M. Fernández-Morilla, Sustainability, 10(10), 3698 (2018).

9. M. Brassler, J. Dettmers, Interdisciplinary Journal of Problem-Based Learning, 11, 2 (2017)

10. E. Faham, A. Rezvanfar, S. H. M.Mohammadi, M. R. Nohooji, Technological Forecasting and Social Change, 123, 307 (2017)

11. G.Cebrián, M. Junyent, I. Mulà, Competencies in education for sustainable development: Emerging teaching and research developments (2020)

12. M. Jelonek, M. Urbaniec, Sustainability, 11(20), 5716 (2019)

13. W. Lambrechts, E. Verhulst, S. Rymenams, International journal of sustainability in higher education, 18(5), 697 (2017)

14. R. Lozano, M. Y. Merrill, K. Sammalisto, K. Ceulemans, F. J. Lozano, Sustainability, 9(10), 1889 (2017)

15. L. Mindt, M. Rieckmann, Teoría de la Educación; Revista Interuniversitaria, 29(1), 129 (2017)

16. S. Sterling, H. Glasser, M. Rieckmann, P. Warwick, Envisioning futures for environmental and sustainability education, 153 (2017)

17. J. Dlouhá, R Heras, I. Mulà, F. P. Salgado, L. Henderson, Sustainability, 11, 13 (2019)

18. A. Krechetov, A. Khoreshok, V. Blumenstein, EDP Sciences, 20 (2017)

19. K. F. Mulder, Renewable and Sustainable Energy Reviews, 68, 1106 (2017)

20. M. Sahakian, G. Seyfang, Journal of cleaner production, 198, 231 (2018)

21. K. Shephard, M. Rieckmann, M. Barth, Environmental Education Research, 25(4), 532 (2019)

22. Yu. A. Shukshina, O. V. Suldina, Humanities and education, 10(1), 90 (2019)

23. G. Tejedor, et al., Sustainability, 11(7), 2086 (2019)

24. C. Valor, P. Antonetti, A. Merino, Journal of Cleaner Production, 248 (2020)

25. V. Zuzeviciute, B. Praneviciene, Z. Simanaviciene, V. Vasiliauskiene, Montenegrin Journal of Economics, 13(4), 121 (2017)

26. O. Alvarez-García, J. Sureda-Negre, R. Comas-Forgas, International Journal of Sustainability in Higher Education, 19(1), 15 (2018)

27. K. Brundiers, M. Barth, G. Cebrián, et al., Sustainability Science, 16(1), 13 (2021)

28. Y. N. Demssie, R. Wesselink, H. J. Biemans, M. Mulder, Journal of Cleaner Production, 221, 828 (2019)

29. A. Eizaguirre, M. García-Feijoo, J. P. Laka, Sustainability, 11, 8 (2019)

30. W. Lambrechts, W. T. Paul, et al., Journal of cleaner production, 202, 561 (2018)

31. W. Lambrechts, C. J. Gelderman, J. Semeijn, E. Verhoeven, Journal of Cleaner Production, 208, 1631 (2019)

32. Lozano, R., Barreiro-Gen, M., Lozano, F. J., \& Sammalisto, K., Sustainability, 11(6), 1602 (2019)

33. I. Molderez, E. Fonseca, Journal of cleaner production, 172, 4397 (2018) 
34. O. L. G. Quelhas, G. B. A. Lima, et al., International Journal of Sustainability in Higher Education, 20(4), 614 (2019)

35. F. S. Carracedo, et al., International Journal of Engineering Education, 5, 1527 (2018)

36. H. Schulze, L. Bals, T. E. Johnsen, International Journal of Physical Distribution \& Logistics Management, 49(3), 287 (2019)

37. E. M. Waltner, W. Rieß, C. Mischo, Sustainability, 11(6), 1717 (2019)

38. W. Lambrechts, I. Mulà, et al., Journal of Cleaner Production, 48, 65 (2013)

39. Taimur S., Sattar H. Quality Education. Encyclopedia of the UN Sustainable Development Goals (2019) 